JPE (Jurnal Pendidikan Edutama) Vol. 6 No. 2 Januari 2019

P-ISSN : 2339-2258 (Print) E-ISSN: 2548-821X (Online)

http://ejurnal.ikippgribojonegoro.ac.id/index.php/JPE

\title{
PROGRAM PETUGAS KEDISIPLINAN KELAS: INOVASI PENANAMAN KARAKTER DISIPLIN DI SEKOLAH DASAR
}

\author{
Rifka Anisa ${ }^{1)}$, Mohammad Adam Jerusalem ${ }^{2)}$ \\ 1)Program Pascasarjana, Universitas Negeri Yogyakarta \\ email: rifkaanisa.2017@student.uny.ac.id \\ ${ }^{2}$ Fakultas Teknik, Universitas Negeri Yogyakarta \\ email: adam_jerusalem@uny.ac.id
}

\begin{abstract}
This article aims to explore the innovation program of class discipline officers to instill the value of discipline character in elementary school students. This article describes in a straightforward and in-depth manner about a program innovation created by the teacher with a student center approach and in accordance with the characteristics of elementary school students. The research design used in this article is qualitative research with a type of case study research involving 6 students, 1 teacher, and 1 principal for in-depth and comprehensive interviews. The results showed that there were three steps in carrying out the disciplinary officer program namely planning, implementing and evaluating. Class discipline officers are innovations in character education programs where students act as officers to maintain discipline and class discipline. This program-centered approach makes students gain real experience so that it is easy for students to understand. Therefore, this class discipline disciplinary program is suitable for application in elementary schools. Contributions in this study are expected to be able to: 1) Provide input in increasing attention in instilling the values of student discipline. 2) Increase awareness for schools to integrate discipline values in formulating school activities policies and programs.
\end{abstract}

Keywords: class discipline officier, discipline character

\begin{abstract}
Abstrak: Artikel ini bertujuan mengeksplorasi inovasi program petugas kedisiplinan kelas untuk menanamkan nilai karakter disiplin pada siswa sekolah dasar. Artikel ini mendeskripsikan secara lugas dan mendalam mengenai suatu inovasi program yang diciptakan guru dengan pendekatan student center dan sesuai dengan karakteristik siswa sekolah dasar. Desain penelitian yang digunakan dalam artikel ini yakni penelitian kualitatif dengan jenis penelitian studi kasus yang melibatkan 6 siswa, 1 guru, dan 1 kepala sekolah untuk wawancara secara mendalam dan komprehensif. Hasil penelitian menunjukkan bahwa terdapat tiga langkah dalam melaksanakan program petugas kedisiplinan kelas yakni perencanaan, pelaksanaan, dan evaluasi. Petugas kedisiplinan kelas merupakan inovasi program pendidikan karakter dimana siswa yang berperan sebagai petugas guna menjaga kedisiplinan dan ketertibab kelas. Pendekatan yang berpusat pada program ini membuat siswa mendapatkan pengalaman secara nyata sehingga mudah dipahami siswa. Oleh karena itu, program petugas kedisiplinan kelas ini cocok untuk diterapkan di sekolah dasar. Kontribusi dalam penelitian ini yakni diharapkan mampu: 1) Memberikan masukan dalam meningkatkan perhatian dalam menanamkan nilai kedisiplinan siswa. 2)Meningkatkan kesadaran bagi sekolah untuk mengintegrasikan nilai kedisiplinan dalam merumuskan kebijakan dan program kegiatan sekolah.
\end{abstract}

Kata kunci: petugas kedisiplinan kelas, karakter disiplin. 


\section{PENDAHULUAN}

Karakter telah menjadi suatu keharusan bagi dunia pendidikan. Berdasarkan penelitian yang dilakukan Goss \& Holt (2014), pendidikan karakter memiliki dampak positif pada pemahaman siswa sebagai anggota masyarakat yang baik sesuai dengan yang diharapkan lingkungan. Hal inilah yang menyebabkan pemerintah gencar mencanangkan program pendidikan karakter dalam kurikulum terbaru. Fenomena-fenomena yang menunjukkan degradasi moral juga menjadi salah satu hal yang melatarbelakangi dunia pendidikan harus mengedepankan aspek moral dan karakter siswa. Salah satu karakter yang sangat penting untuk ditanamkan sejak dini yakni karakter disiplin.

Disiplin merupakan suatu tindakan yang menunjukkan ketaatan atau sikap patuh pada aturan (Anitah, dkk., 2009). Artinya disiplin berkaitan dengan pengendalian seseorang dalam menyikapi peraturan untuk ditaati. Selain itu disiplin dapat diartikan sebagai sikap patuh dengan sukarela terhadap pemimpin (Sutirna, 2013). Disiplin tidak hanya mampu menjadikan sesuatu lebih tertib dan teratur (Zuriah, 2015), namun juga dapat mengendalikan diri dari perbuatan menyimpang karena seseoran akan dituntut untuk patuh terhadap aturan yang ada di masyarakat setempat (Mustari \& Rahman, 2011). Oleh karena itu, karakter disiplin penting untuk ditanamkan sejak dini karena membuat sesorang mampu memahami batasanbatasan dalam bertingkah laku sehingga menjadi lebih baik, tertib, tertur, dan sesuai dengan harapan kelompok masyarakat.

Masalah utama dalam karakter disiplin yakni semakin maraknya penyimpangan nilai disiplin. Misalnya membuang sampah sembarangan yang mengakibatkan banjir dan pencemaran lingkungan, pelanggaran lalu lintas yang menimbulkan tingginya angka kecelakaan meningkat, dan penebangan pohon sembarangan yang mengakibatkan longsor, serta pelanggaranpelanggaran lainnya. Contoh-contoh pelanggaran juga terjadi di lingkungan sekolah seperti terlambat masuk kelas, membolos, tidak mengerjakan tugas, tidak menggunakan seragam sesuai aturan, dan pelangaran-pelanggaran lainnya. Hal ini menjadi permasalahan yang serius, karena kedisiplinan merupakan salah satu faktor keberhasilan dalam suatu pembelajaran.

Hasil penelitian menunjukkan kedisiplinan dapat mempengaruhi hasil belajar siswa (Elly, 2016). Penelitian lain juga membuktikan bahwa tingkat kedisiplinan siswa sangat mempengaruhi prestasi yang dicapai siswa, siswa yang berprestasi memiliki tingkat kedisiplinan yang tertinggi diantara teman-temannya (Baumann \& Krskova, 2016). Hal ini dikarenakan pembelajaran akan nyaman apabila siswa mentaati peraturan dari guru. Para siswa yang disiplin akan menciptakan suasana kelas yang tenang sehingga memungkinkan siswa belajar dengan baik dan menghasilkan prestasi yang lebih baik (Baumann \& Krskova, 2016).

Disiplin mampu mendorong tumbuhnya karakter-karakter baik lainnya. Seseorang yang mampu menjalankan tugas sesuai harapan masyarakat akan mudah diterima dan diakui oleh lingkungan sekitarnya. Hasil penelitian yang dilakukan terhadap anak usia Sekolah Dasar menunjukkan disiplin terhadap tata tertib mampu membentuk akhlak siswa (Prasetya, 2016). Hal ini dikarenakan siswa akan menjadi terbiasa hidup dengan teratur untuk mematuhi segala aturan maupun norma yang telah ditetapkan di lingkungannya. Oleh karena itu, siswa akan dengan sendirinya mampu menjadi individu yang memiliki karakter yang diinginkan oleh lingkungan sekitarnya.

Sekolah menjadi salah tempat yang efektif untuk menanamkan nilai-nilai 
karakter. Sekolah dipandang sebagai lembaga yang mampu mendidik siswa sehingga memiliki kemampuan akademik dan moral menjadi lebih baik (Johanson, et al., 2011). Selain itu, salah satu tugas sekolah yakni mengembangkan nilai karakter pada siswa (Lickona, 2011). Oleh karena itu, sangat penting bagi sekolah melakukan inovasi progam pendidikan untuk mengembangkan dan menginternalisasi nilai-nilai karakter.

Berdasarkan paparan di atas dapat ditarik kesimpulan betapa pentingnya nilai karakter disiplin dan sekoah menjadi salah satu tempat yang efektif untuk menanamkan karakter disiplin. SD N 1 Pandowan merupakan salah satu sekolah yang memiliki inovasi program pengembangan nilai karakter. Program tersebut adalah program petugas kedisiplinan kelas. Program ini merupakan inovasi dari salah satu guru kelas VI yang diterapkan di kelas guna menanamkan nilai kedisiplinan siswa.

Berdasarkan dari temuan lapangan, maka perlu mengetahui lebih dalam tentang bagaimana pelaksanaan program petugas kedisiplinan kelas. Program ini merupakan salah satu strategi penanaman nilai yakni melalu kegiatan yang diprogramkan (Muslich, 2011). Kegiatan yang diprogramkan memerlukan serangkaian tahapan yakni perencanaan, pelaksanaan, dan evaluasi (Kemendiknas, 2010; Jabar, dkk., 2016).

Penelitian mengenai program petugas kedisiplinan kelas dalam menanamkan karakter disiplin siswa belum pernah dilakukan. Mempertimbangkan hal tersebut, maka dilakukan penelitian lebih jauh tentang penanaman karakter disiplin melalui program kedisiplinan kelas.

Hasil-hasil penelitian yang ada menunjukkan program pendidikan karakter efektif dalam menanamkan nilai-nilai karakter. Penelitian yang telah dilakukan tentang pendidikan karakter pada umumnya menyajikan pendidikan karakter yang diintegrasikan ke dalam mata pelajaran. Afandi (2011) menyatakan pendidikan karakter dapat diintegrasikan ke dalam mata pelajaran IPS pada jenjang sekolah dasar. Akan tetapi penelitian ini belum menyajikan secara praktik nyata bagaimana penanaman pkarakter melalui mata pelajaran IPS. Penelitian ini menyajikan teori-teori yang kuat, namun tidak disertai dengan tindakan nyata.

Penelitian yang dilakukan oleh Jamarudi, Gafur, \& Suardiman (2014) menunjukkan bahwa model pembelajaran sangat berperan penting terhadap penanaman karakter siswa. Penelitian ini memiliki kesamaan dengan penelitian tentang petugas kedisiplinan kelas yakni sama-sama tentang program inovatif penanaman karakter di dalam kelas. Akan tetapi penanaman karakter di sini masih terbatas pada karakter religius dan guru masih menjadi tokoh utama dalam pelaksanaanya.

Penelitian yang relevan yang ketiga yakni penelitian yang dilakukan oleh Wuryandani, Maftuh, Sapriya \& Budimansyah (2014). Hasil penlitian menunjukkan internalisasi nilai karakter disiplin yang terpenting adalah pembiasaan sehari-hari di sekolah. Siswa akan mendapatkan pengalaman yang nyata apabila siswa melakukannya secara langsung. Penelitian ini memiliki kesamaan dengan penelitian yang akan dilakukan yakni sama-sama menempatkan siswa sebagai pelaku langsung dalam proses penanaman nilai karakter serta mengadakan evaluasi berupa refleksi secara rutin. Hal yang membedakan yakni penelitian ini lebih pada membisaakan diri pada siswa bukan memberikan tanggung jawab kepada siswa untuk menjaga kedisiplinan.

Penelitian yang relevan yang ketiga yakni penelitian yang dilakukan oleh 
Nuriyah (2015). Hasil penelitian ini menyajikan upaya meminimalisir pelanggran tata tertib melalui tiga tahapan yakni preventif, kuratif, dan represif. Penelitian ini memiliki kesamaan pada upaya penanaman nilai disiplin yakni mengatasi pelanggaran yang terjadi di sekolah. Selain itu, penelitian ini juga menunjukkan adanya program yang dilakukan oleh sekolah untuk menanamkan karakter disiplin pada siswa. Akan tetapi terdapat perbedaan, penelitian ini lebih menekankan peran guru bukan pada peran siswa sebagai tokoh utama dalam upaya menjalankan program sekolah tersebut.

Penelitian-penelitian

tersebut menguraikan berbagai cara menanamkan nilai-nilai karakter. Akan tetapi, belum ada yang membahas mengenai program yang diterapkan di dalam kelas seperti program petugas kedisiplinan yang memberikan tanggung jawab kepada siswa.

Program petugas kedisiplinan kelas menarik untuk dibahas karena dapat memberikan referensi penanaman karakter disiplin yang sesuai dengan karakteristik siswa sekolah dasar. Selain itu penelitian diharapkan mampu meningkatkan kesadaran akan pentingnya karakter disiplin dan memberikan masukan dalam merumuskan program kegiatan sekolah dalam menanamkan karakter disiplin. Penelitian ini akan mengungkap bagaimana pelaksanaan program petugas kedisiplinan kelas melalui wawancara, observasi, dan mengumpulkan dokumen-dokumen yang dimiliki sekolah. Penelitian ini hanya akan membahas bagaimana implementasi petugas kedisiplinan kelas dalam penanaman karakter disiplin siswa kelas VI SD N 1 Pandowan.

\section{METODE PENELITIAN}

Penelitian ini merupakan penelitian kualitatif dengan jenis penelitian studi kasus. Hal ini dikarenakan penelitian ini bertujuan untuk menganalisis secara mendalam terhadap suatu kasus yakni suatu program yang dilakukan oleh sekolah (Creswell, 2017). Program yang dimaksud yaitu program petugas kedsisplinan kelas. Penelitian ini dilakukan di SD Negeri 1 Pandowan. Subjek penelitian ini adalah 1 kepala sekolah, 6 siswa, dan 1 guru. Teknik pengumpulan data dalam pennelitian ini meliputi wawancara, observasi, dan dokumentasi.

Wawancara digunakan untuk mengumpulkan informasi dengan mengajukan pertanyaan terbuka sehingga partispan dapat membagikan informasi yang dimilikinya tanpa terbatas oleh perspektif peneliti atau temuan sebelumnya (Creswell, 2015). Observasi bertujuan untuk mengamati objek yang akan diteliti untuk memperoleh data (Satori \& Komariah, 2011). Penggunaan dokumen dalam studi kasus yakni untuk menambah dan mendukung bukti dari sumber-sumber lain (Yin, 2014). Teknik keabsahan data yang digunakan yakni dengan teknik triangulasi yakni dengan triangulasi teknik dan triangulasi sumber (Sugiyono, 2012). Sementara untuk teknik analisis data yakni menggunakan teknik analisis induktif. Teknik analisis induktif merupakan analisis yang bermuara pada simpulan umum (Creswell, 2017). Langkah-langkah analisis data tersebut meliputi reduksi data, kategorisasi, display data, dan penarikan kesimpulan.

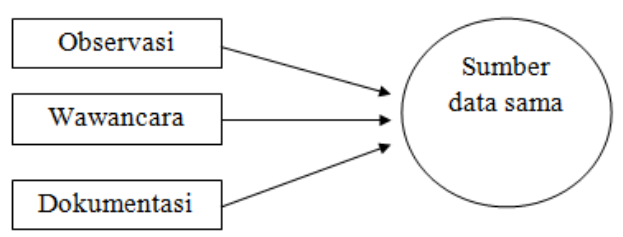

Gambar 1. Triangulasi Teknik

(Sugiyono, 2012) 


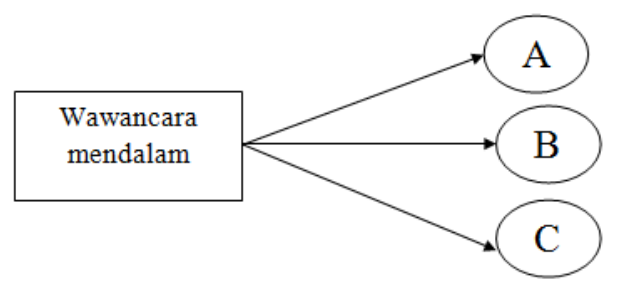

Gambar 2. Triangulasi Sumber

(Sugiyono, 2012)

\section{HASIL DAN PEMBAHASAN}

\section{A. Hasil}

1. Perencanaan

Perencanaan program petugas kedisiplinan di awali dengan pembentukan kepengurusan kelas. Siswa dipandu oleh guru menyusun kepengurusan kelas di awal semester. Kemudian siswa dan guru membuat kesepakatan-kesepakatan aturan kelas beserta dengan sanksinya. Hasil wawancara dengan beberapa siswa menyatakan ada beberapa aturan yang telah disepakati siswa dan guru di awal semester 1 adalah sebagai berikut.

\begin{tabular}{|c|c|c|}
\hline No & Aturan & Sanksi \\
\hline 1 & Harus mengerjakan PR & $\begin{array}{l}\text { Jika tidak mengerjakan PR mengerjakan di kantor } \\
\text { guru dan meminta tanda tangan semua guru }\end{array}$ \\
\hline 2 & Harus melaksanakan piket sesuai jadwal & Jika tidak piket membayar Rp. 2000,00 \\
\hline 3 & Tidak membuat teman menangis & Jika membuat teman menangis denda Rp. 500,00 \\
\hline 4 & Kuku diperiksa setiap hari Jumat & Jika kuku tidak bersih atau panjang denda Rp. 500,00 \\
\hline 5 & Berpakaian rapi sesuai aturan sekolah & $\begin{array}{l}\text { Jika tidak berpakaian rapi menulis surat pernyataan } \\
\text { yang di tanda tangani orang tua }\end{array}$ \\
\hline
\end{tabular}

Hasil dokumentasi ada beberapa aturan yang dicatat oleh siswa terdapat pada gambar 3 sebagai berikut.

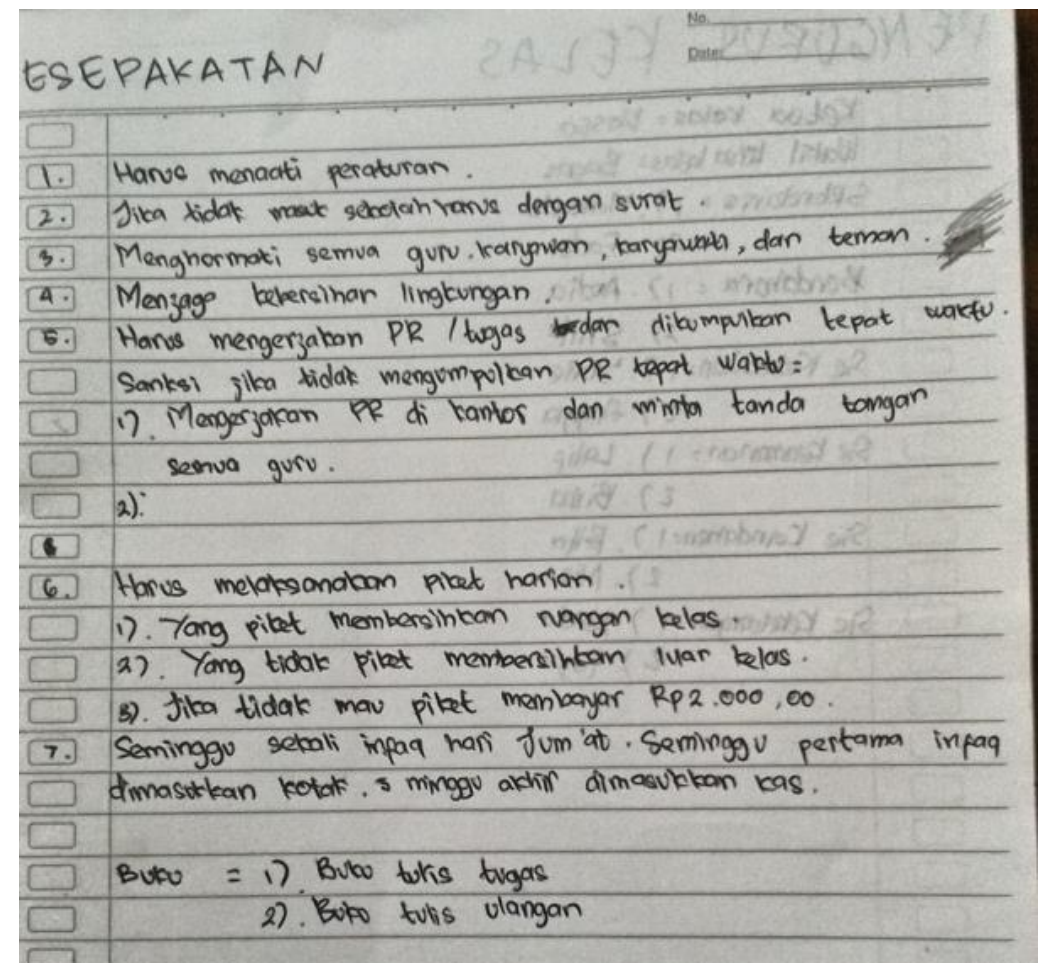


2. Pelaksanaan

Tanggung jawab pengurus kedisiplinan kelas yakni mengawasi teman-temannya, apabila ada yang melanggar dicatat dan dilaporkan kepada guru. Apabila sanksi berupa denda petugas akan melaporkan juga pada bendahara. Hasil observasi menunjukkan siswa benar-benar melakukan pemeriksaan setiap hari. Siswa tidak takut untuk menegur siswa yang melanggar kemudian mencatatnya. Hasil dokumentasi juga menunjukkan banyak catatan pernyataan siswa yang berjanji untuk tidak mengulangi kesalahannya. Catatan ini biasanya akan ditunjukkan guru saat mengadakan pertemuan rutin dengan orang tua/ wali siswa.

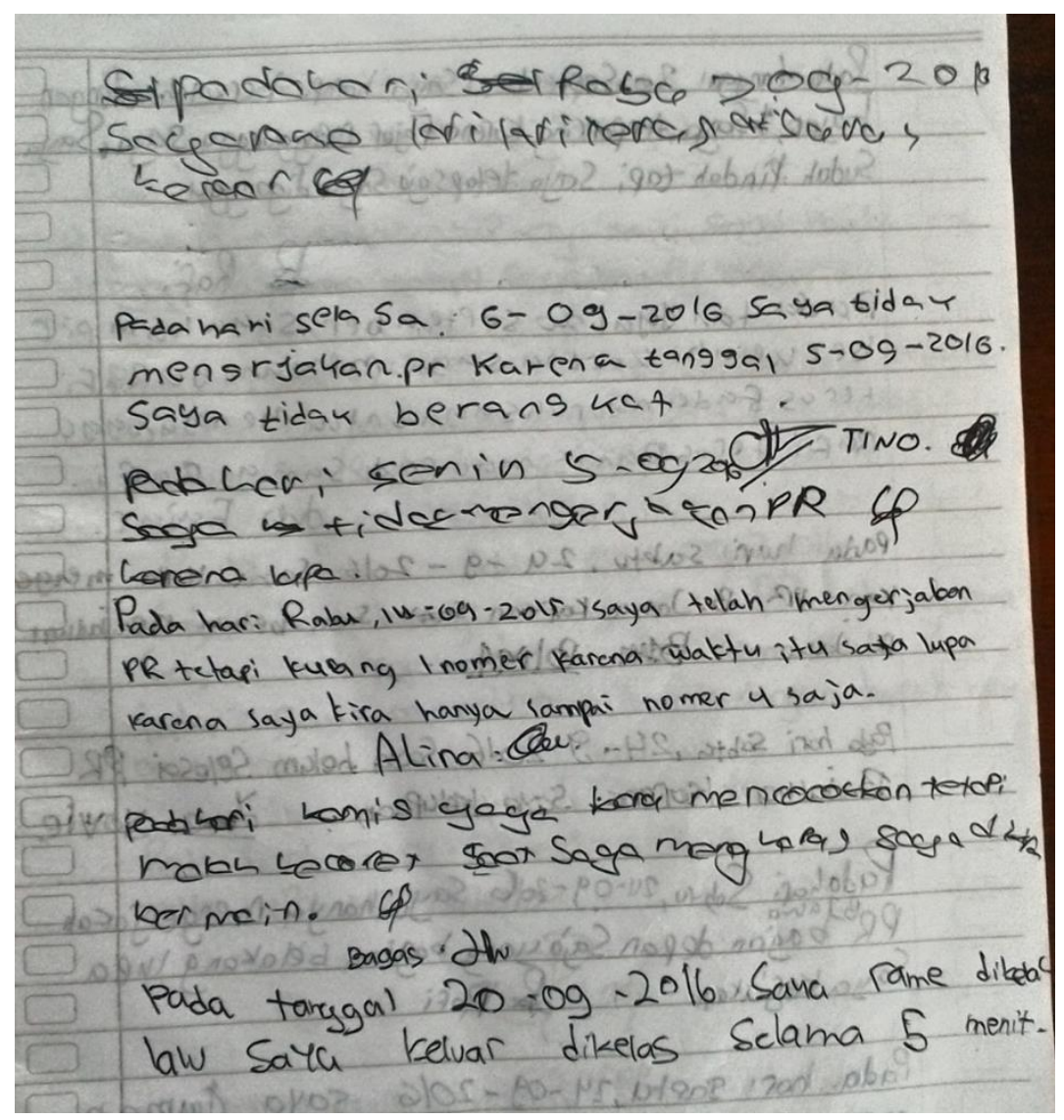

\section{Evaluasi}

Guru melakukan evaluasi setiap akhir pekan. Kegiatan evaluasi diisi dengan nasehat-nasehat dari guru serta motivasi kepada siswa agar menjadi anak yang lebih baik lagi daripada hari kemarin. Selain itu, ketika diadakan pertemuan rutin dengan orang tua/wali siswa guru melaporkan sikap dan perilaku siswa di sekolah. Guru berusaha membangun kerja sama dengan orang tua/wali siswa dalam penanaman nilai karakter pada siswa.

\section{B. Pembahasan}

Guru-guru di SD Negeri 1 Pandowan menanamkan karakter disiplin melalui kegiatan yang diprogramkan. Kegiatan yang diprogramkan merupakan salah satu strategi pengeintegrasian nilai-nilai karakter (Muslich, 2011). Hal ini ditunjukkan dengan kegiatan-kegiatan terjadwal seperti upacara hari senin, piket, dan pembelajaran yang terintegrasi dengan pendidikan karakter yang tercantum di RPP. Selain kegiatan-kegiatan program tersebut, 
kegiatan unuk juga diterapkan di kelas VI yakni program petugas kedisiplinan kelas. Uniknya program ini bukan program yang ditulis dalam perencanaan sekolah baik dalam kegiatan sekolah maupun dalam RPP. Akan tetapi program ini merupakan inovasi dari guru kelas VI. Perencanaan program ini dilakukan pada awal semester 1. Siswa dipandu guru mengadakan diskusi guna membentuk pengurus kelas termasuk petugas kedisiplinan kelas. Hal ini berbeda dengan esensi perencanaan dalam menanamkan pendidikan karakter. Perencanaan dalam penanaman nilai karakter melalui integrasi kegiatan yang diprogramkan yakni dengan mencantumkan nilai-nilai yang akan ditanamkan di RPP dan pada perencanaan program kegiatan sekolah (Kemendiknas, 2010). Akan tetapi, guru tidak mencantumkannya dalam RPP, namun guru membuat kesepakatan secara lisan dan tertulis. Perencanaan sangat penting dilakukan, kegiatan tanpa adanya perencanaan berarti telah merencanakan suatu kegagalan (Sa'ud \& Makmun, 2005).

Pelaksanaan progam petugas kedisiplinan kelas dilakukan oleh siswa dengan pengawasan guru. Siswa yang bertanggung jawab akan memeriksa dan mencatat siapa saja siswa yang melanggar, kemudian melaporkan kepada guru dan bendahara kelas. Ki Hajar Dewantara menyatakan sudah selayaknya sebagai guru tidak hanya memberi contoh namun harus mampu mendorong siswa untuk ke depan dan mampu bertanggung jawab atau yang sering dikenal dengan ing madyo mangun karso (Anitah, dkk., 2010). Siswa yang diberikan tanggung jawab akan merasa dirinya dianggap dan dipercaya. Guru sudah seharusnya tidak lagi terlalu menjadi penguasa kelas dengan mendikte siswa, namun memberikan kesempatan siswa untuk melakukan dan mengambil keputusan. Memberikan kepercayaan dan tanggung jawab kepada siswa membuat siswa berlatih bertanggung jawab dalam melaksanakan kedisiplinan dan membangun kepribadian siswa yang lebih baik (Anitah, dkk., 2010).

Evaluasi dilakukan dengan memberikan nasehat-nasehat dan motivasi di akhir pekan. Selain itu, guru juga melaporkan setiap sikap dan perilaku siswa di sekolah kepada orang tua/wali siswa ketika mengadakan pertemuan rutin. Tujuannya agar orang tua / wali turut mendidik dan mengajarkan nilai-nilai karakter di rumah dan melakukan pengawasan secara intensif di rumah. Peran orang tua sangat penting dalam penanaman nilai karakter. Pembiasaan orang tua dalam kehidupan sehari-hari sangat mempengaruhi karakter siswa (Ginanjar, 2013; Hasanah, 2017; Lestari, dkk., 2015). Evaluasi ini diharapkan agar siswa tidak mengulangi kesalahan yang telah diperbuat. Selain itu, tujuan dilakukan evaluasi ini yakni mengetahui apakah capaian tujuan sesuai dengan rencana atau tidak (Suhardan, dkk., 2017).

Setelah program ini berjalan, dalam kurun waktu satu semester pelanggaranpelanggaran siswa terbukti semakin berkurang. Catatan pelanggaran semakin berkurang setiap harinya. Hal ini membuktikan program petugas kedisiplinan kelas mampu secara perlahan menanamkan karakter disiplin siswa. Siswa sebagai pelaku utama dalam pelaksanaan pendidikan karakter memberikan pengalaman langsung dan pemahaman konsep secara nyata. Siswa belajar akan ada konsekuensi yang diterima apabila siswa melalukan segala sesuatu. Hal ini membuat siswa memahami pentingnya berpikir dahulu sebelum bertindak. Program petugas kedisiplinan kelas ini dapat diterapkan secara efektif di kelas tinggi. Hal ini dikarenakan karakteristik siswa kelas tinggi yang sudah mampu berpikir secara realistis (Izzaty, dkk., 2013). 


\section{SIMPULAN}

Penanaman nilai karakter yang paling penting yakni harus diperhatikan dalam proses penanaman nilai karakter disiplin di sekolah, khususnya sekolah dasar. Hal ini mengingat bahwa proses penanaman nilai karakter disiplin akan lebih mudah diterima oleh siswa ketika nilai-nilai karakter tersebut dialami langsung oleh siswa melalui aktivitas kelas sehari-hari, bukan karena didikte oleh guru. Kegiatan yang dilakukan guru pada program petugas kedisiplinan kelas pada tahap perencanaan adalah membentuk pengurus atau petugas kelas termasuk petugas kedisiplinan kelas dan membuat kesepatakatan-kesepakatan bersama. Selanjutnya, pada tahap pelaksanaan pembelajaran, guru perlu mengawasi proses pelaksanaan petugas kedisiplinan kelas yang telah direncanakan, dan menjaga konsistensi dalam penerapan aturan sekolah maupun aturan kelas. Pada tahap akhir yaitu evaluasi, guru perlu melakuukan refleksi tentang perilaku disiplin siswa setiap akhir pekan.

Penelitian ini dapat memberikan gambaran inovasi penanaman nilai karakter disiplin melalui program petugas kedisiplinan kelas mulai dari perencanaan hingga evaluasi. Sehingga penelitian ini diharapkan dapat bermanfaat untuk menanamkan nilai karakter disiplin siswa. Selain itu, penelitian tentang progam kedisiplinan kelas dapat diterapkan untuk kelas tinggi. Selain itu penelitian ini diharapkan mampu memberikan masukan dan meningkatkan kesadaran sekolah untuk mengintegrasikan pendidikan karakter disiplin dalam rumusan program sekolah.

Penelitian ini tidak membahas seberapa efektif program petugas kedisiplinan kelas dalam menanamkan karakter disiplin siswa serta belum menguraikan program petugas kedisiplinan kelas diterapkan di kelas rendah, sehingga dapat dilakukan penelitian lebih lanjut. Hambatan-hambatan dalam penelitian ini yakni guru tidak mendokumentasikan seluruh perencanaan maupun pelaksanaan program petugas kedisiplinan kelas.

\section{DAFTAR RUJUKAN}

Afandi, R. (2011). Integrasi pendidikan karakter dalam pembelajaran IPS di sekolah dasar. Pedagogia, 1(1), 85-98.

Anitah, W. S., dkk. (2009). Strategi pembelajaran di SD. Jakarta: Universitas Terbuka.

Baumann, C \& Krskova, H. (2016). School discipline, school uniforms and academic performance. International Educational Management, 30(6), 1003-1029.

Creswell, J. W. (2015). Educational research: Planning, conducting, and evaluating quantitative and qualitative, 5th edition. New York: Pearson Education, Inch.

\section{(2017). Research}

design: Qualitative, quantitative, and mixed methods approaches, 4th edition. London: Sage Publication.

Elly, R. (2016). Hubungan kedisiplinan terhadap hasil belajar siswa kelas V SD Negeri 10 Banda Aceh. Jurnal Pesona Dasar, 3(4), 43-53.

Ginanjar, M. H. (2013). Keseimbangan peran orang tua dalam pembentukan karakter anak. Edukasi Islami Jurnal Pendidikan Islam, 2, 230-242.

Goss, S. J \& Holt, C. R. (2014). Perceived impact of a character education program at a midwest rural middle school: A case study. National Council of Professors of Educational Administration (NCPEA), 1(2), 49-64. 
Hasanah, N (2017). Peran orang tua dalam pendidikan karakter anak usia dini melalui ranah afektif. Prosiding Seminar Nasional Tahunan Fakultas Ilmu Sosial Universitas Negeri Medan, 1(1), 371374.

Izzaty, R. E., dkk. (2013). Perkembangan peserta didik. Yogyakarta: UNYPress.

Jabar, C. S. A., dkk. (2016). Manajemen pendidikan. Yogyakarta: UNYPress.

Jamarudi, Gafur, A., \& Suardiman, S. P. (2014). Pengembangan model pembelajaran humanis religius dalam pendidikan karakter di sekolah dasar. Jurnal Pembangunan Pendidikan: Fondasi dan Aplikasi, 2(2), 114-129.

Johansson, E., et al. (2011). "Practices for teaching moral values in the early years: A call for a pedagogy of participation". Education, Citizenship and Social Justice, 6 (2), 109-124.

Kemendiknas. (2010). Pengembangan pendidikan budaya dan karakter bangsa. Jakarta: Kemendiknas.

Lestari, A. P., dkk. (2015). Pengembangan karakter siswa melalui pendekatan guru dan orang tua. Jurnal Pengabdian pada Masyarakat, 30(1), 26-29.

Lickona, T. (2011). Educating for character. New York: Bantam Books.

Muslich, M. (2011). Pendidikan karakter: Menjawab tantangan krisis multidimensional. Jakarta: Bumi Aksara.

Mustari, M \& Rahman, M. T. (2011). Nilai karakter: Refleksi untuk pendidikan karakter. Yogyakarta: LaksBang Pressindo.

Nuriyah, E. S. (2015). Tata tertib sekolah sebagai sarana pendidikan karakter di SDN Pekuwon III Sumberejo tahun pelajaran 2011/2012. Jurnal Edutama, 2(1), 50-62.

Prasetya, S. (2016). Pengaruh disiplin tata tertib terhadap pembentukan akhlak siswa. Jurnal Eksekutif, 13(2), 249263.

Satori, D \& Komariah, A. (2011). Metodologi penelitian kualitatif. Bandung: Alfabeta.

Sa'ud, U. S dan Makmun, A. S. (2005). Perencanaan pendidikan: Suatu pendekatan komprehensif. Bandung: Remaja Rosdakarya

Suhardan, D., dkk. (2017). Manajemen pendidikan. Bandung: Penerbit Alfabeta.

Sugiyono. (2012). Memahami penelitian kualitatif. Bandung: Alfabeta.

Sutirna. (2013). Perkembangan \& pertumbuhan peserta didik. Yogyakarta: Andi Offset.

Wuryandani, W., Maftuh, B., Sapriya, Budimansyah, D. (2014). Internalisasi nilai karakter disiplin melalui penciptaan iklim kelas yang kondusif di SD Muhammadiyah Sapen Yogyakarta. Jurnal Pendidikan Karakter, 4(2), 175-184.

Yin, R. K. (2014). Case study research: Design and methods. New York: The Guilford Press.

Zuriah, N. (2015). Pendidikan moral dan budi pekerti dalam perspektif perubahan. Jakarta: Bumi Aksara. 
86 JURNAL PENDIDIKAN EDUTAMA, Vol 6, No. 2, Juli 2019 